\begin{tabular}{l|c|c}
\hline ISSN: 0001-5113 & ACTA ADRIAT., & ORIGINAL SCIENTIFIC PAPER \\
AADRAY & $58(2): 209-224,2017$ & \\
\hline
\end{tabular}

\title{
Metazoan parasites of trachinid fishes (Teleostei: Trachinidae) from Tunisian coasts (Mediterranean Sea)
}

\author{
Ramla AZIZI, Chiraz YEMMEN* and Sihem BAHRI \\ Research Unit of Integrative Biology and Evolutionary and Functional Ecology of Aquatic \\ Systems, Faculty of Sciences of Tunis, University of Tunis El Manar, Tunis, Tunisia
}

*Corresponding author, e-mail: chiraz_yemmen@yahoo.fr

A parasitological survey of Trachinus draco Linnaeus, 1758; Trachinus araneus Cuvier, 1829 and Trachinus radiatus Cuvier, 1829 collected from Tunisian coasts was performed from January 2014 to January 2015. In total, 18 species of metazoan parasites belonging to 13 genera were found: nine Myxozoa, four Nematoda, one Cestoda, one Digenea, one Monogenea, one Isopoda and one Annelida Hirudinea. Data on morphology, location and infection levels of parasites were provided. The higher species richness was recorded in Trachinus draco (18 species), while Trachinus radiatus and Trachinus araneus harbored 9 and 7 species, respectively. Species richness and diversity according to the host species and the sampling sites based on the Simpson and Shannon-Wiener indices are reported.

Key words: Trachinidae fish, Metazoan parasites, species richness, Tunisia

\section{INTRODUCTION}

Trachinids (Teleostei: Trachinidae) are a family of benthic marine fish living on sandy or muddy bottoms, typically on the continental shelf but also in deeper waters of 150 to 200 $\mathrm{m}$. These fish have a wide distribution through the eastern Atlantic coasts, Mediterranean Sea and Black Sea. In Tunisia, the most commonly known species of trachinids are: the greater weever, (Trachinus draco), the spotted weever, (Trachinus araneus) and the starry weever (Trachinus radiatus). Several studies have been performed on the metazoan parasites of trachinids through the word (DILLON \& HARGIS, 1965; ORRECHIA \& PAGGI, 1978; GEORGES, 1982; PETTER \& MAILLARD, 1988; TRILLES et al., 1989; CANNING et al., 1999; HORTON, 2000; AKMIRZA,
2004; ÖKTENER \& TRILLES, 2004; FARJALLAH et al., 2008). Nevertheless, in Tunisia, only two studies have been achieved on trachinid fishes, AZIZI et al. (2016) described a new species of myxosporean Zschokkella trachini from the gallbladder of Trachinus draco and FARJALLAH et al. (2008) who reported the nematode Anisakis pegreffi parasite of $T$. draco. Parasitic diseases may influence weight, reproduction, growth and survival of the host, inducing significant economic losses in fish production particularly in aquaculture. Therefore, data on biodiversity and ecology of parasites in natural ecosystems, the nature of the host/parasite relationship and the possible use of parasites as biological tags are very important in terms of conservation. In order to expand our knowledge on the biodiversity of trachinids parasites, we have undertaken a parasitological 


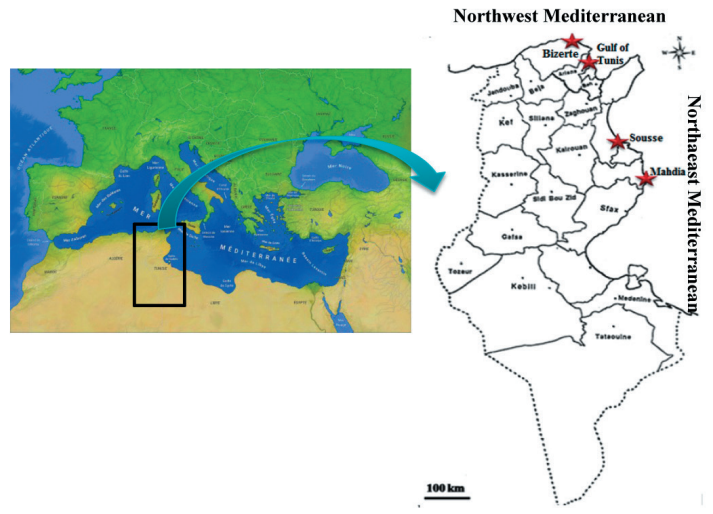

Fig. 1. Map showing the locations of the 4 sampling sites

survey from four different sites along the Tunisian coasts.

\section{MATERIAL AND METHODS}

From January 2014 to January 2015, a total of 703 trachinid fishes belonging to Trachinus draco, Trachinus araneus and Trachinus radiatus were collected monthly from four marine regions in Tunisia, located in the northern coast: Bay of Bizerte $\left(37^{\circ} 20^{\prime} \mathrm{N}, 9^{\circ} 53^{\prime} \mathrm{E}\right)$ and Gulf of Tunis $\left(36^{\circ} 49^{\prime} \mathrm{N}, 10^{\circ} 18^{\prime} \mathrm{E}\right)$ and in the eastern coast: Sousse ( $35^{\circ} 50^{\prime} \mathrm{N}, 10^{\circ} 38^{\prime}$ ) and Mahdia ( $35^{\circ} 29^{\prime}$ $\left.\mathrm{N}, 11^{\circ} 3^{\prime} \mathrm{E}\right)$. The number of examined specimens and the range of total length (TL) according to the locality are given in the Table 1 . In the labo- ratory fish were examined for the presence of ectoparasites and endoparasites. Therefore, skin, fins, gills, eyes body cavity and viscera were examined carefully macroscopically and microscopically. All organs and body fluids were examined as well. Fresh spores of myxosporean isolated from gallbladders were measured according to the guidelines of LOM \& ARTHUR (1989). Measurements were based on 30 fresh spores and data were presented as mean $\pm \mathrm{SD}$ (range). Permanent preparation of monogeneans, digeneans and cestods were made according to JUSTINE et al. (2012). Nematodes isolated from the abdominal cavity and intestine were fixed in $70 \%$ ethanol, cleared in Amann lactophenol and studied by direct examination between slide and cover slip. Isopods isolated from the body surface and fins were fixed in $70 \%$ ethanol. All measurements were carried out using micrometric ocular. Isopods and annelids were photographed under a stereo microscope however the other parasites were photographed with a Canon Power Shot A2500 digital camera mounted on a Nikon E600 microscope using DIC optics. The prevalence, mean intensity and mean abundance were determined according to BUSH et al. (1997). Parasite diversity was described on the bases of the Simpson, and Shannon-Wiener indices. These indices were calculated according to MAGURRAN (1988).

Table 1. Number and range of total length (TL) of the examined hosts according to the locality

\begin{tabular}{llll}
\hline Species & Locality & Number & Range of TL (mm) \\
\hline \multirow{4}{*}{ T. draco } & Bay of Bizerte & 190 & $21.5-30.5$ \\
& Sousse & 110 & $15.5-28.5$ \\
T. araneus & Mahdia & 156 & $19.5-29.5$ \\
& Gulf of Tunis & 65 & $15.5-23.5$ \\
& Bay of Bizerte & 26 & $19.5-34.5$ \\
T. radiatus & Sousse & 18 & $23.5-34.8$ \\
& Mahdia & 47 & $21.5-33.9$ \\
& Gulf of Tunis & 0 & - \\
& Bay of Bizerte & 27 & $19.5-35.9$ \\
& Sousse & 18 & $14.5-31.5$ \\
& Mahdia & 46 & $14.5-34.5$ \\
\hline
\end{tabular}




\section{RESULTS}

\section{Composition of the parasite communities}

A total of 18 parasite species representing 13 genera were collected from trachinid fishes: Ceratomyxa Thélohan, 1892, Zschokkella Auerbach, 1910, Ortholinea Shulman, 1962, Myxidium Bütschli, 1882, Chloromyxum Mingazzini, 1980, Gnathia Leach, 1814, Helicometra Odhner, 1902, Aspinatrium Yamaguti, 1963, Bothriocephalus Rudolphi, 1808, Stribarobdella Leigh-sharpe, 1925, Anisakis Dujardin, 1845, Hysterothylacium Rudolphi, 1819, and Philometra Costa, 1845. Data on the prevalence, mean intensity, mean abundance, site of infection and locality of parasite species are given in the Table 2.

\section{Myxozoa}

Myxosporean was the most diverse group found during the present study, nine species were collected from trachinids (Table 2; Fig.
2). Only two species have been reported in trachinid fishes from different geographical areas: Myxidium trachinorum Canning, Curry, Anderson \& Okamura, 1999 and Zschokkella trachini Azizi, Rangel, Castro, Santos \& Bahri, 2016. However, other species belonging to the genera Ceratomyxa, Chloromyxum and Ortholinea were unidentified (Table 3). In the present study, infection by myxosporean species was recorded on fish during summer, winter and spring. The highest infection occurred in summer. Significant differences in the prevalence of infection by myxosporean were found between localities $(\mathrm{df}=3, \mathrm{P}<0.05)$.

\section{Cestoda}

Bothriocephalus scorpii Müller, 1776 was the only cestod found in the examined fish (Table 2;Fig. 3). This species was found in the intestine of $T$. draco, T. radiatus and T. araneus from the Bay of Bizerte, during spring and summer. The maximum prevalence $(33 \%)$ and the maximum mean intensity $(2 \pm 4)$ were noted in

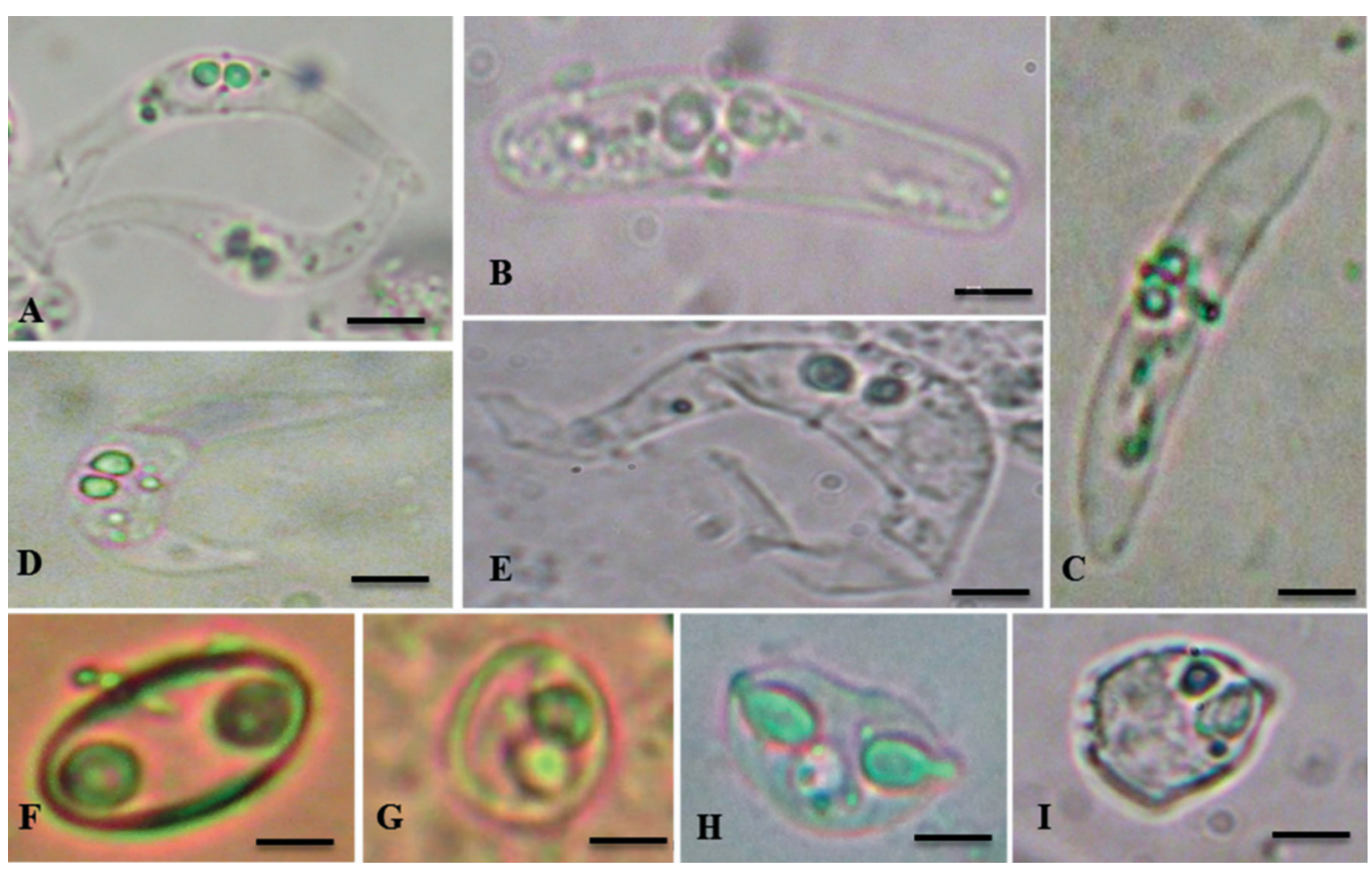

Fig. 2. Mature spores of Myxosporean species isolated from trachinid fishs from Tunisian coasts. A: Ceratomyxa sp. 1; $B$ : Ceratomyxa sp. 2; $C$ : Ceratomyxa sp. 3; D: Ceratomyxa sp. 4; E: Ceratomyxa sp. 5; F: Zschokkella trachini; $G$ : Ortholinea sp.; H: Myxidium trachinorum; I: Chloromyxum sp. (Scale bars $=8 \mu \mathrm{m}$ ) 
Table 2: List of parasite species found on Trachinidfishes from Tunisian coasts and their infection rates

N.I.F: Number of infected fish; N.P: Total number of parasite specimens; Ac: Abdominal cavity; G: Gill; GB: Gallbladder; B: Body; In: Intestin; Ovary: O

\begin{tabular}{|c|c|c|c|c|c|c|}
\hline $\begin{array}{l}\text { Parasites } \\
\text { Species }\end{array}$ & Host species & Locality & $\begin{array}{l}\text { Site of } \\
\text { infection }\end{array}$ & $\begin{array}{l}\text { Prevalence } \\
(\%)\end{array}$ & $\begin{array}{l}\text { Mean } \\
\text { intensity }\end{array}$ & $\begin{array}{l}\text { Mean } \\
\text { abundance }\end{array}$ \\
\hline \multicolumn{7}{|l|}{ Myxozoa } \\
\hline Ceratomyxa sp. 1 & T. draco & $\begin{array}{l}\text { Bay of Bizerte } \\
\text { Sousse } \\
\text { Mahdia }\end{array}$ & $\begin{array}{l}\text { GB } \\
\text { GB } \\
\text { GB }\end{array}$ & $\begin{array}{l}49.4 \\
46.3 \\
41.5\end{array}$ & $\begin{array}{l}36 \pm 24 \\
48 \pm 31 \\
35 \pm 12\end{array}$ & $\begin{array}{l}17.8 \\
22.2 \\
14.5\end{array}$ \\
\hline Ceratomyxa sp. 2 & T. draco & $\begin{array}{l}\text { Bay of Bizerte } \\
\text { Sousse } \\
\text { Mahdia }\end{array}$ & $\begin{array}{l}\text { GB } \\
\text { GB } \\
\text { GB }\end{array}$ & $\begin{array}{l}33.7 \\
27.2 \\
17.8\end{array}$ & $\begin{array}{l}62 \pm 27 \\
49 \pm 9 \\
35 \pm 14\end{array}$ & $\begin{array}{l}11 \\
13.3 \\
11.8\end{array}$ \\
\hline \multirow{2}{*}{ Ceratomyxa sp. 3} & $\begin{array}{l}\text { T. araneus } \\
\text { T. draco }\end{array}$ & $\begin{array}{l}\text { Bay of Bizerte } \\
\text { Mahdia } \\
\text { Bay of Bizerte } \\
\text { Mahdia }\end{array}$ & $\begin{array}{l}\text { GB } \\
\text { GB } \\
\text { GB }\end{array}$ & $\begin{array}{l}24.8 \\
21.3 \\
57.2 \\
44.2\end{array}$ & $\begin{array}{l}51 \pm 22 \\
64 \pm 16 \\
36 \pm 14 \\
41 \pm 32\end{array}$ & $\begin{array}{l}27.9 \\
26.4 \\
15.9 \\
19.3\end{array}$ \\
\hline & T. araneus & $\begin{array}{l}\text { Bay of Bizerte } \\
\text { Mahdia }\end{array}$ & $\begin{array}{l}\text { GB } \\
\text { GB }\end{array}$ & $\begin{array}{l}31.0 \\
23.8\end{array}$ & $\begin{array}{l}46 \pm 22 \\
46 \pm 13\end{array}$ & $\begin{array}{l}10.9 \\
14.2\end{array}$ \\
\hline \multirow{2}{*}{ Ceratomyxa sp. 4} & T. draco & Bay of Bizerte & GB & 26.2 & $42 \pm 16$ & 7.5 \\
\hline & T. araneus & Bay of Bizerte & GB & 17.8 & $39 \pm 09$ & 10.2 \\
\hline Ceratomyxa sp. 5 & T. draco & $\begin{array}{l}\text { Bay of Bizerte } \\
\text { Gulf of Tunis } \\
\text { Sousse } \\
\text { Mahdia }\end{array}$ & $\begin{array}{l}\text { GB } \\
\text { GB } \\
\text { GB } \\
\text { GB }\end{array}$ & $\begin{array}{l}46.3 \\
36.9 \\
27.9 \\
33.6\end{array}$ & $\begin{array}{l}38 \pm 19 \\
31 \pm 21 \\
39 \pm 19 \\
32 \pm 27\end{array}$ & $\begin{array}{l}12.8 \\
11.6 \\
10.9 \\
14.8\end{array}$ \\
\hline \multirow{2}{*}{$\begin{array}{l}\text { Zschokkella } \\
\text { trachini } \\
\text { Azizi, Rangel, Severino, } \\
\text { Santos \& Bahri, } 2016\end{array}$} & T. draco & $\begin{array}{l}\text { Bay of Bizerte } \\
\text { Gulf of Tunis } \\
\text { Sousse } \\
\text { Mahdia }\end{array}$ & $\begin{array}{l}\text { GB } \\
\text { GB } \\
\text { GB } \\
\text { GB }\end{array}$ & $\begin{array}{l}57.8 \\
43.0 \\
53.8 \\
49.0\end{array}$ & $\begin{array}{l}74 \pm 05 \\
71 \pm 11 \\
64 \pm 09 \\
62 \pm 17\end{array}$ & $\begin{array}{l}42.8 \\
30.5 \\
34.4 \\
30.4\end{array}$ \\
\hline & T. radiatus & $\begin{array}{l}\text { Bay of Bizerte } \\
\text { Mahdia }\end{array}$ & $\begin{array}{l}\text { GB } \\
\text { GB }\end{array}$ & $\begin{array}{l}41.1 \\
24.4\end{array}$ & $\begin{array}{l}68 \pm 21 \\
71 \pm 16\end{array}$ & $\begin{array}{l}28 \\
17.3\end{array}$ \\
\hline Ortholinea $s p$. & T. draco & $\begin{array}{l}\text { Bay of Bizerte } \\
\text { Mahdia }\end{array}$ & $\begin{array}{l}\text { GB } \\
\text { GB }\end{array}$ & $\begin{array}{l}38.1 \\
20\end{array}$ & $\begin{array}{l}46 \pm 16 \\
62 \pm 12\end{array}$ & $\begin{array}{l}9.2 \\
17.4\end{array}$ \\
\hline \multirow{3}{*}{$\begin{array}{l}\text { Myxidium trachinorum } \\
\text { Canning, Curry, Anderson } \\
\text { \& Okamura, } 1999\end{array}$} & T. radiatus & $\begin{array}{l}\text { Bay of Bizerte } \\
\text { Mahdia }\end{array}$ & $\begin{array}{l}\text { GB } \\
\text { GB }\end{array}$ & $\begin{array}{l}39.4 \\
26.6\end{array}$ & $\begin{array}{l}36 \pm 26 \\
38 \pm 14\end{array}$ & $\begin{array}{l}10.5 \\
10.1\end{array}$ \\
\hline & T. draco & $\begin{array}{l}\text { Bay of Bizerte } \\
\text { Gulf of Tunis } \\
\text { Sousse } \\
\text { Mahdia }\end{array}$ & $\begin{array}{l}\text { GB } \\
\text { GB } \\
\text { GB } \\
\text { GB }\end{array}$ & $\begin{array}{l}49.1 \\
35.3 \\
43.6 \\
21.1\end{array}$ & $\begin{array}{l}42 \pm 17 \\
42 \pm 11 \\
54 \pm 09 \\
38 \pm 21\end{array}$ & $\begin{array}{l}18.3 \\
28.4 \\
23.8 \\
18.6\end{array}$ \\
\hline & T. radiatus & $\begin{array}{l}\text { Bay of Bizerte } \\
\text { Mahdia }\end{array}$ & $\begin{array}{l}\text { GB } \\
\text { GB }\end{array}$ & $\begin{array}{l}38.2 \\
23.3\end{array}$ & $\begin{array}{l}54 \pm 07 \\
48 \pm 15\end{array}$ & $\begin{array}{l}19 \\
16\end{array}$ \\
\hline Chloromyxum sp. & T. draco & Bay of Bizerte & GB & 0.5 & $14 \pm 07$ & 0.07 \\
\hline
\end{tabular}




\section{Cestoda}

Bothriocephalus scorpii Müller, 1776

T. draco

T. araneus

Bay of Bizerte

T. radiatus

In

85.4

75.3

72.7

47.8

Sousse

Mahdia

In, Ac

In, Ac

In, Ac

In, Ac

In, Ac

62

Sousse

Mahdia

T. radiatus

Bay of Bizerte Sousse

Mahdia

Hysterothylacium sp.

T. draco

Bay of Bizerte

Gulf of Tunis

Sousse

Mahdia

T. radiatus

Bay of Bizerte

Sousse

T. draco

Rudolphi, 1819

( $3^{\text {rd }}$ larval stage)

Hysterothylacium fabri

Rudolphi, 1819

(4 $4^{\text {rd }}$ larval stage)

Philometra sp.

\section{Digenea}

Helicometra fasciata

Rudolphi, 1819

Monogenea

Aspiatrium trachini

Parona \& Perugia, 1889

In, Ac $\quad 62.2$

56.2

47

50.5

36.9

40.9

41.0

In, Ac

In, Ac

In, Ac

In, Ac

35.2

In, Ac

21.1

In, Ac

Bay of Bizerte
Sousse
Mahdia

In, Ac

75.4

62.3

54.7

$\begin{array}{ll}\text { T.draco } & \begin{array}{l}\text { Bizerte } \\ \text { Sousse } \\ \text { Mahdia }\end{array} \\ \text { T. radiatus } & \begin{array}{l}\text { Bay of Bizerte } \\ \text { Mahdia }\end{array}\end{array}$

In, Ac

70.9

In, Ac

61

44.2

In, Ac

47.0

28.6

In, Ac

5.7

T. draco $\quad$ Bay of Bizerte In

4.21

$\begin{array}{lccccc}\text { T. draco } & \text { Bay of Bizerte } & \text { G } & 16.8 & 2 \pm 1 & 0.06 \\ \text { T. radiatus } & \text { Bay of Bizerte } & \text { G } & 19.8 & 3 \pm 2 & 0.6 \\ \text { T. araneus } & \text { Bay of Bizerte } & \text { G } & 18.1 & 3 \pm 2 & 0.3\end{array}$

$\begin{array}{ll}21.1 \pm 2.6 & 9.4 \\ 15.1 \pm 3.2 & 11.4 \\ 10.7 \pm 0.9 & 0.7 \\ 10.2 \pm 1.3 & 8.7\end{array}$

$2 \pm 4$

0.1

0.8

$5.7 \pm 0.9 \quad 2$

$10.8 \pm 1.3 \quad 3.3$

$2.9 \pm 0.5 \quad 1.6$

$2.5 \pm 1.2 \quad 1.5$

$1.9 \pm 2.4 \quad 1.4$

$6.2 \pm 0.7 \quad 2.7$

$8.0 \pm 2.1 \quad 4.8$

$8.8 \pm 0.5 \quad 4.1$

$2 \pm 1.4$

0.04

$1.6 \pm 0.5$

0.06

1. araneus

Bay of Bizerte
18.

0.3 
Isopoda

Gnathia $s p$

T. draco

Bay of Bizerte B Gulf of Tunis G

Sousse

Mahdia

T. radiatus

Bay of Bizerte

Sousse

Mahdia

T. araneus

Bay of Bizerte

Sousse

Mahdia

T. draco

Gulf of Tunis

G

0.01

Schmarda, 1861

Table 3. Spores measurements ( $\mu \mathrm{m})$ of myxosporean spp. parasite of trachinid fishes. D: Diameter, L: length, W: width

\begin{tabular}{llll}
\hline Species & Spore Length & Spore Width & Size of Polar Capsule \\
\hline Ceratomyxa sp. 1 & $9.2 \pm 1.4(8-11)$ & $49.2 \pm 1.9(48-52)$ & D: $3.5 \pm 0.4(3.2-4)$ \\
Ceratomyxa sp. 2 & $7 \pm 2.3(6-9)$ & $24.8 \pm 1.6(24-28)$ & D: $3.5 \pm 0.2(3.0-4.0)$ \\
Ceratomyxa sp. 3 & 8 & $48.7 \pm 1.5(48-52)$ & D: $3.6 \pm 0.4(3.2-4)$ \\
Ceratomyxa sp. 4 & 8 & $39 \pm 1(38-40)$ & D: 4 \\
Ceratomyxa sp. 5 & $10.8 \pm 1.8(8-12)$ & $40.7 \pm 1.5(40-42)$ & D: $3.6 \pm 0.4(3.2-4)$ \\
Ortholinea sp. & $10.1 \pm 0.57(9-11)$ & $12.3 \pm 0.64(12-14)$ & D: 5 \\
Chloromyxum sp. & $13.1 \pm 0.6(13-13.3)$ & $10.3 \pm 0.6(10.2-10.5)$ & L:3 $\pm 0.6, \mathrm{~W}: 1.7 \pm 0.4$ \\
\hline
\end{tabular}

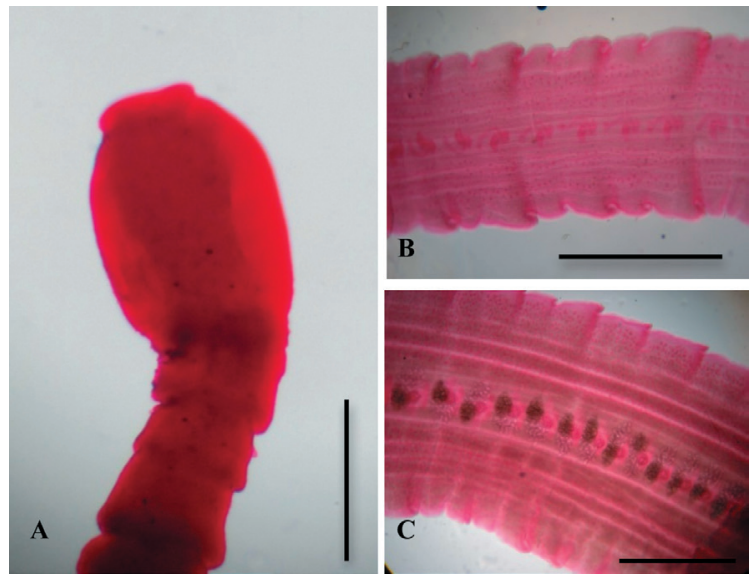

Fig.3. Bothriocephalus scorpii from the intestin of trachinid fishes. A: Scolex; B: Immature proglottis; C: Mature proglottis
T. araneus. However, there was no significant difference in the prevalence of infection by Bothriocephalus scorpii between host species $(\mathrm{df}=2, \mathrm{P}>0.05)$.

\section{Nematoda}

Four nematode species were recorded during the sampling period. These species were found along the four seasons with maximum level of infection in summer.

Anisakis sp. (Table 2; Fig. 4) was collected from the intestine and the abdominal cavity of T. draco from the Bay of Bizerte, Gulf of Tunis, Sousse and Mahdia, and also from T. araneus and $T$. radiatus found in the previous locali- 


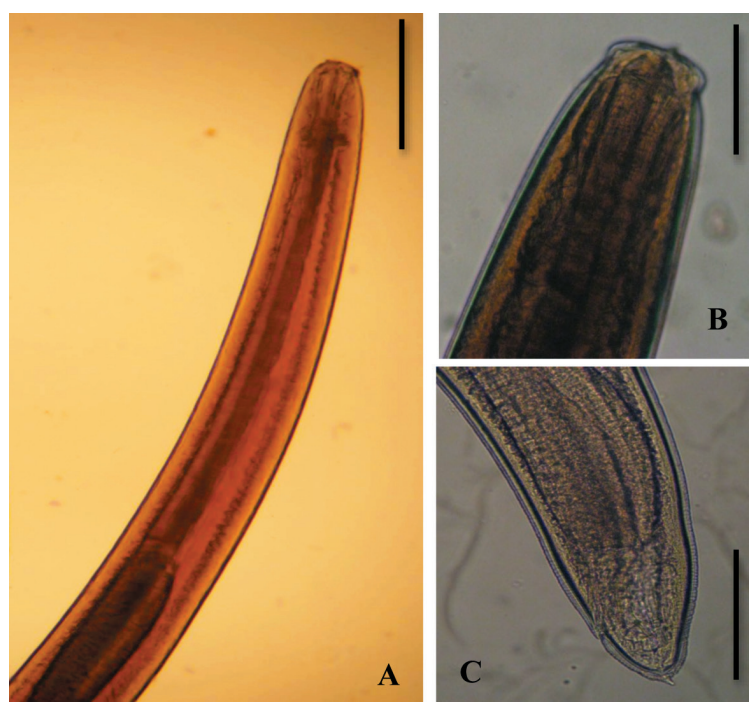

Fig. 4. Anisakis simplex from the intestine of trachinid fishes. A: Anterior part of body; B: Lateral view of cephalic end; $C$ : Lateral view of caudal end. (Scale bars: $A=0.5 \mathrm{~mm} ; B, C=0.2 \mathrm{~mm}$ )

ties except in the Gulf of Tunis where they are absent. The prevalence of infection was relatively higher in all infected fish and varied from $38 \%$ to $85.4 \%$. The maximum mean intensity $(21.1 \pm 2.6)$ was noted in T. draco from the Bay of Bizerte. There was a significant difference in the prevalence of infection between localities $(\mathrm{df}=2, \mathrm{P}<0.05)$.

Hysterothylacium sp. (Table 2; Fig. 5) was collected from the abdominal cavity and the
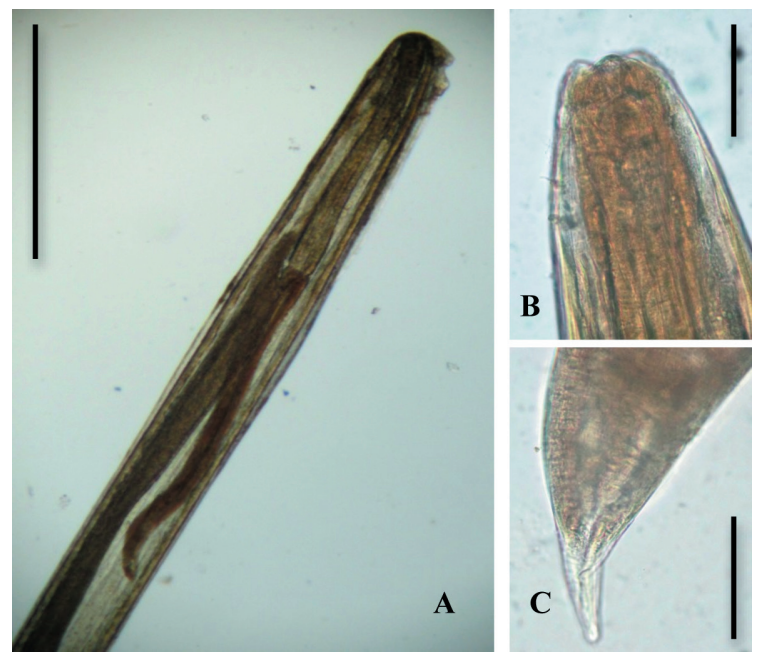

Fig. 5. Hysterothylacium sp. from the intestine of trachinid fishes. A: ventrtal view of body and anterior region; $B$ : Lateral view of cephalic end; $C$ : Lateral view of caudal end. (Scale bars: $A=0.5 \mathrm{~mm} ; B, C=0.1 \mathrm{~mm}$ ) intestine of $T$. draco from the Bay of Bizerte, Gulf of Tunis, Sousse and Mahdia, and from the body cavity and the intestine of $T$. radiatus from the Bay of Bizerte and Sousse. Maximum prevalence of this species was noted in T. draco from the Bay of Bizerte with $50.5 \%$ and the maximum mean intensity $(10.8 \pm 2.4)$ was registered in T. draco from the Gulf of Tunis. A significant difference in the prevalence of infection between the localities was noted $(\mathrm{df}=3, \mathrm{P}<$ $0.05)$.

Hysterothylacium fabri Rudolphi, 1819 (3rd larval stage) (Table 2; Fig. 6) was collected from the abdominal cavity and the intestine of $T$. draco from the Bay of Bizerte, Sousse and Mahdia. However, Hysterothylacium fabri Rudolphi, 1819 (4rd larval stage) was collected from the body cavity and the intestine of T. draco from the Bay of Bizerte, Sousse and Mahdia, and T. radiatus from the Bay of Bizerte and Mahdia. The maximum prevalence of Hysterothylacium fabri (third and fourth-stage

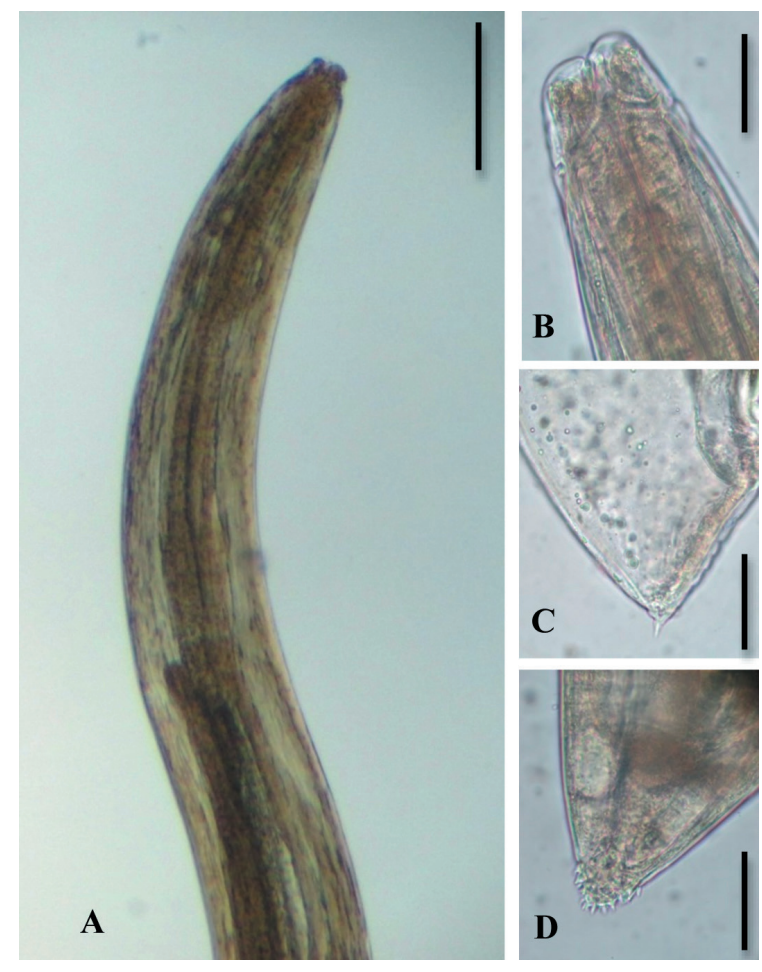

Fig .6. Hysterothylacium fabri from the intestine of trachinid fishes. A: Anterior part of body; B: Lateral view of cephalic end of; $C$ : Lateral view of caudal end of the 3rd larval stage; D: Lateral view of caudal end of the 4 rd larval stage. (Scale bars: $0.5 \mathrm{~mm}$ ) 


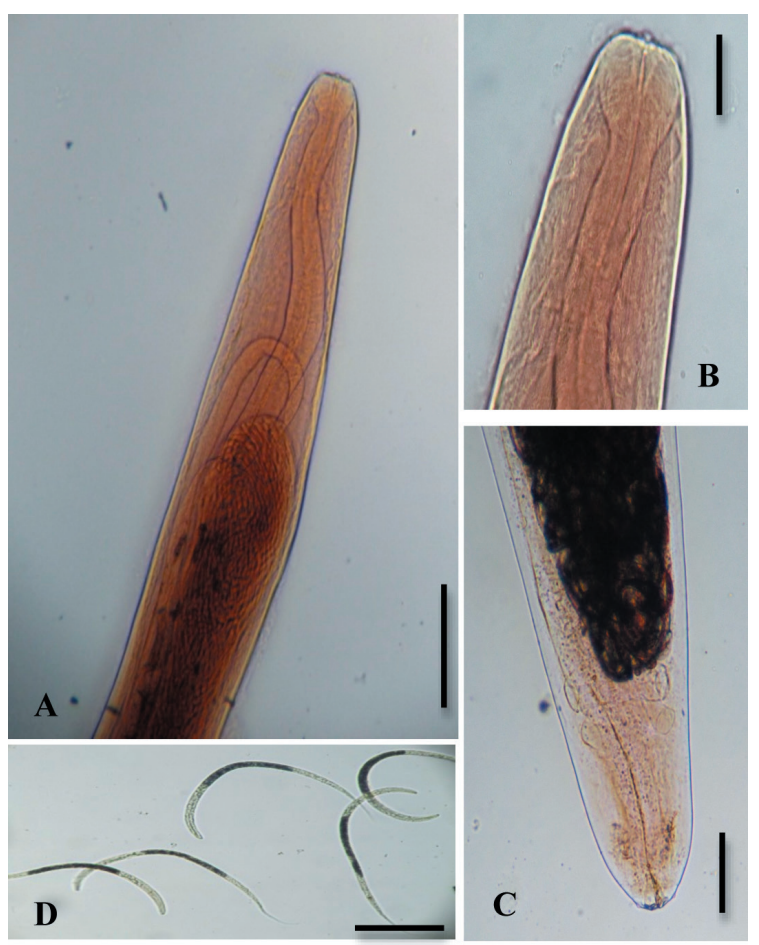

Fig. 7. Philometra sp. from the ovary of trachinidfishes. A: Anterior part of body; B: Lateral view of cephalic end of; $C$ : Lateral view of caudal end; D: Larva from uterus. (Scale bars: $A, B, C=0.5 \mathrm{~mm} ; D=0.1 \mathrm{~mm}$ )

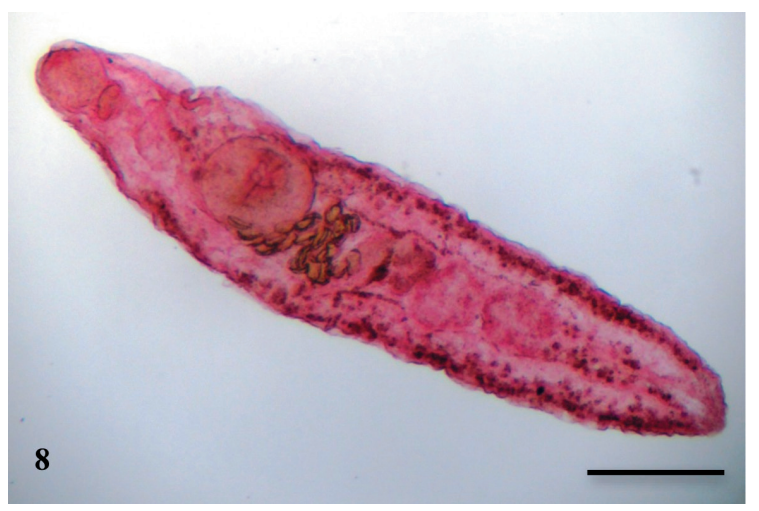

Fig. 8. Helicometra fasciata from the intestine of trachinid fishes. Scale bar: $0.5 \mathrm{~mm}$ larvae) was observed in T. draco from the Bay of Bizerte with respectively $75.4 \%$ and $70.9 \%$. The maximum mean intensity was noted for the fourth-stage larvae of $H$. fabri in T. radiatus from the Bay of Bizerte with $8.8 \pm 0.5$. There was significant difference in the prevalence between localities $(\mathrm{df}=3, \mathrm{P}<0.05)$.

Philometra sp. (Table 2; Fig. 7) infecting the ovary of $T$. draco from the Bay of Bizerte was collected with a prevalence of $5.7 \%$, and a mean intensity of $2 \pm 1$. The main measurements of Anisakis sp. , Hysterothylacium sp. and Philometra sp. collected from trachinid fishes are reported in table 4 .

\section{Monogenea}

Aspinatrium trachini Parona \& Perugia, 1889 (Table 2; Fig. 9) was collected from the gills of $T$. draco, T. radiatus and T. araneus from the Bay of Bizerte. The maximum prevalence (19.8\%) and mean intensity (22) of A. trachini were recorded in $T$. radiatus. No significant difference was found in the prevalence of infection between host species $(\mathrm{df}=2, \mathrm{P}>0.05)$.

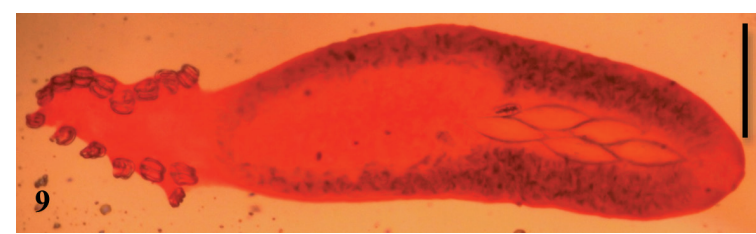

Fig. 9. Aspinatrium trachini from the gills of trachinidfishes. Scale bar: $2 \mathrm{~cm}$

\section{Isopoda}

Praniza larvae of Gnathia sp. (Table 2, Fig. 10) were collected from the gills and the body surface of $T$. draco, $T$. radiatus and $T$. araneus from the Bay of Bizerte, Sousse, Mahdia and Gulf

Table 4. Morphometric measurements $(\mathrm{mm})$ of nematode species parasite of trachinid fishes

\begin{tabular}{lccccc}
\hline Species & $\begin{array}{c}\text { Total } \\
\text { length }\end{array}$ & $\begin{array}{c}\text { Maximum } \\
\text { width }\end{array}$ & Nerve ring & $\begin{array}{c}\text { Oesophagus } \\
\text { length }\end{array}$ & $\begin{array}{c}\text { Ventriculus } \\
\text { length }\end{array}$ \\
\hline Anisakis sp. & $18-20.3$ & $0.3-0.4$ & $0.26-0.28$ & $1.56-1.60$ & $0.23-0.25$ \\
Hysterothylacium sp. & $12.6-16.5$ & $0.13-0.38$ & $0.14-043$ & $0.25-1.13$ & $0.07-0.15$ \\
Philometra sp. & $46.3-52.3$ & $0.2-0.3$ & - & - & - \\
\hline
\end{tabular}




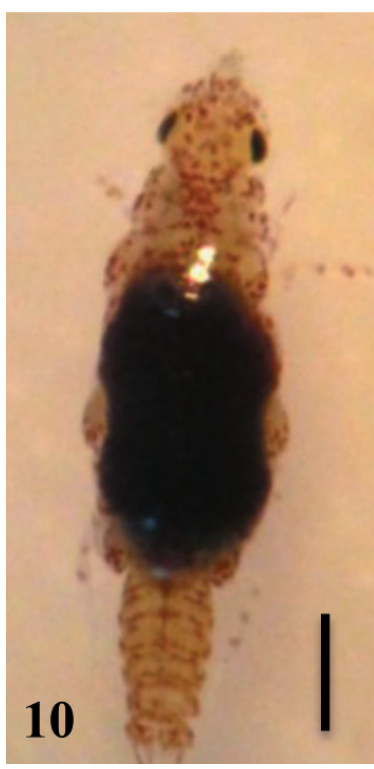

Fig. 10. Gnathia sp. from the gills of trachinid fishes. Scale bar: $1 \mathrm{~mm}$

\section{Hirudinea}

Stibarobdella loricata Schmarda, 1861 parasitizing gills of T. draco (Table 2, Fig. 11) was collected in spring from the Gulf of Tunis with low prevalence (1\%) and mean intensity (1).

\section{Parasite diversity}

For the study of parasite diversity of Trachnids from Tunisian coasts, three measures of biodiversity were considered: the species richness (SR), Shannon-Weaver index (H') and Simpson index (D). The different fish species presented component communities with different diversity; each fish-host presented at least seven parasites species. The richest component community was in T. draco with 18 parasites species followed by $T$. radiatus (8 species) and $T$. araneus ( 7 species) (Table 5).

The Simpson index varied between 0.14 and 0.54 . The

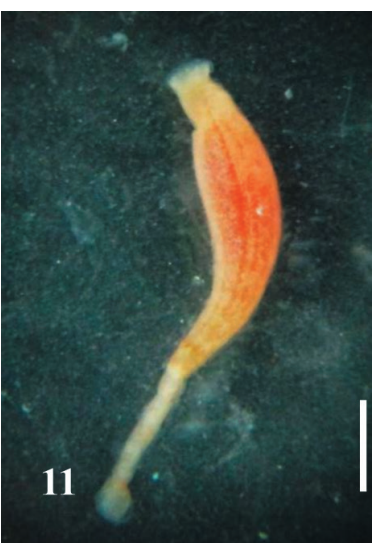

Fig. 11. Stibarobdella loricata from the gills of trachinid fishes. Scale bar: $0.5 \mathrm{~cm}$ highest value (0.54) was noted in T. araneus. Furthermore, T. radiatus and T. draco presented different values of the Simpson index: 0.28 and 0.14 respectively (Table 5 ). The highest value of Shannon-Weaver index of species diversity was observed for the community of $T$. draco (3.11). However, the Shannon-Weaver index was almost the same for $T$. radiatus (2.05) and T. araneus (2.1) (Table 5).

The study of parasite diversity according to the sampling site showed that the Bay of Bizerte presented the most important richness species with 17 parasites species followed by Mahdia with 11 species, Sousse with 9 species and the Gulf of Tunis with 7 species (Table 6). The maximum value of the Simpson index was noted in the Gulf of Tunis (0.26), however the minimum value was observed in the Bay of Bizerte

Table 5. The indicators characteristics of the parasite diversity of the T. draco, T. radiatus and T. araneus

\begin{tabular}{|c|c|c|c|c|}
\hline Index & Host & T. draco & T. radiatus & T. araneus \\
\hline Richness species (RS) & & 19 & 8 & 7 \\
\hline Simpson (D) & & $0.14 \pm 0.29$ & $0.28 \pm 0.12$ & $0.54 \pm 0.43$ \\
\hline Shannon-Weaver (H') & & $3.11 \pm 0.12$ & $2.05 \pm 0.23$ & $2.01 \pm 0.10$ \\
\hline
\end{tabular}

Table 6. The indicators characteristics of the parasite diversity from the different sampling sites

\begin{tabular}{|c|c|c|c|c|c|}
\hline Index & Localities & Bay of Bizerte & Gulf of Tunis & Mahdia & Sousse \\
\hline Richness species (RS) & & 17 & 7 & 11 & 9 \\
\hline Simpson (D) & & $0.12 \pm 0.32$ & $0.26 \pm 0.22$ & $0.13 \pm 0.10$ & $0.19 \pm 0.33$ \\
\hline Shannon-Weaver (H') & & $3.94 \pm 0.18$ & $2.87 \pm 0.20$ & $3.85 \pm 0.28$ & $3,81 \pm 0.5$ \\
\hline
\end{tabular}


(0.12). The Shannon-Weaver index values were relatively higher in all the sampling sites and varied from 2.87 to 3.94 . The maximum value was noted in the Bay of Bizerte (Table 6).

\section{DISCUSSION}

In this study, we provided for the first time a data on metazoan parasites of trachinid fishes from Tunisian coasts and their infection indices. Endoparasites collected from trachinids were most dominant than ectoparasites. Indeed, myxosporeans represent the most species-rich group (nine parasites species). Diversity of myxosporean species can be related to the diversity of actinospores parasitizing the invertebrate hosts (polychaetes) present in the sampling sites. These invertebrate hosts living in the sediment were in direct contact with trachnids, so they can easily be exposed to the myxospores released from these fish.

According to literature, this is the first record of Ceratomyxa spp. in Trachinidae from easterm Mediterranean waters. Ceratomyxa reticularis Thélohan, 1895 was previously reported from the gallbladder of Trachinus draco from Mediterranean coasts off France (EIRAS, 2006). However, this species differs greatly, in dimensions and shape, from the Ceratomyxa species of the present study. Among the 300 Ceratomyxa species previously described from different geographical areas (EIRAS, 2006; GUNTER \& ADLORD, 2010; ROCHA et al., 2015; THABET et al., 2015; MANSOUR et al., 2016), no one was morphologically similar to the specimens found.

Zschokkella trachini Azizi, Rangel, Castro, Santos \& Bahri, 2016 was already described in Trachinus draco from the Bay of Bizerte (AZIZI et al., 2016). In the present work, this species was found in T. radiatus from three localities along the Tunisian coasts (Gulf of Tunis, Sousse and Mahdia).

In this study we report for the first time the presence of Ortholinea $s p$. in trachinid fishes. Ortholinea sp. parasitizing T. draco and T. radiatus from the Bay of Bizerte and Mahdia was morphologically different from the 23 species of the genus Ortholinea available in the litera- ture (LOM \& DYKOVÀ, 2006; ABDEL-GHAFFAR et al., 2008; KARLSBAKK \& KØIE, 2011; RANGEL et al., 2014; ABDEL-BAKI et al., 2015; RANGEL et al., 2016 ).

Myxidium trachinorum previously collected from the gallbladder of lesser weever Echiichthys vipera off England (CANNING et al., 1999) was reported for the first time from the gallbladders of $T$. draco and $T$. radiatus living in Tunisian waters and in the Mediterranean Sea.

In this study we report for the first time the presence of Chloromyxum sp. in Trachinids. Among the 140 species of Chloromyxum described worldwide (EIRAS et al., 2012), only Chloromyxum tanakai Fujita, 1936 collected from Oncorhynchus keta from Japan (EIRAS et al., 2012) is relatively similar to the present one but differs greatly in dimensions. Chloromyxum sp. has been found only in Trachinus draco from the Bay of Bizerte with a very low prevalence $(0.5 \%)$.

In the present work, the prevalence of myxosporeans infection varies in relation to the host species and the sampling site. Indeed, we have noted gradual decreases of prevalence from the north to the center coasst and in the most cases, the maximum values of prevalence were recorded in the Bay of Bizerte. These variations were generally associated to the environmental conditions, specially water temperature that have an important effect on the development of myxosporeans in fish and invertebrate hosts (MCGEORGE et al., 1996; KENT et al., 2001; YOKOYAMA, 2003; CANNING \& OKAMURA, 2004). In fact, during the sampling period we have noted that the high water temperatures were recorded in the Bay of Bizerte $\left(14,1-31,1^{\circ} \mathrm{C}\right)$, followed by the Gulf of Tunis $\left(8-28^{\circ} \mathrm{C}\right)$ then Sousse and Mahdia $\left(11.8^{\circ}-27^{\circ} \mathrm{C}\right)$. These observations showed that the high water temperatures favored the release of actinospores from invertebrate hosts and the development of myxospores within the fish hosts. Other authors (YOKOYAMA et al., 2012; FONTES et al., 2015) reported this finding.

Concerning the nematodes infections, we report for the first time the presence of Philometra sp. in T. draco from Tunisian coasts. In fact, two species of the genus Philometra Costa, 1845 have been previously reported from trachi- 
nid fishes: Philometra filiformis Stossich, 1896 infecting the gonads of $T$. draco from the Adriatic Sea and Italy (STOSSICH, 1896; ORECCHIA \& PAGGI, 1978) and Philometra globiceps Rudolphi, 1819 parasitizing the body cavity of $T$. draco from the Black Sea (MORAVEC, 2006). Nevertheless, Philometra sp. was morphologically different from these two species of Philometra.

In this study, Anisakis sp. was detected in trachinid fishes from Tunisian coasts. According to our knowledge, only the work of FARJALLAH et al. (2008) reported the presence of Anisakis pegreffi (CAMPANA-ROUGET \& BIOCCA, 1955) from T. draco collected from Mahdia. Moreover, we report for the first time the presence of two species of Hysterothylacium in trachinid fishes from the Tunisian coasts.

Prevalence, mean intensity and mean abundance of nematodes in trachinid fishes were variable depending on the host species and the sampling site. Anisakis sp. was the most abundant species, followed by Hysterotylacium fabri, Hysterothylacium $s p$. and Philometra sp. We noted a gradual decrease of the prevalence rate from the north to the central coasts. It seems that infected intermediate hosts of nematodes are more abundant in the north coasts. The variations of the prevalence and the abundance of nematodes were probably related to the type and quantity of food consumed by hosts (BAGHERPOUR et al., 2011; OLASUNMIBO OLUMUYIWA \& OLATUNDE, 2014).

Bothriocephalus scorpii was the only species of cestods collected from trachinids and reported for the first time in the intestine of the three Trachinus species from the Tunisian coasts. Otherwise, this species was also reported in Trachinus draco from Turkey (AKMIRZA, 2004).

Digenean parasites collected in this study were limited to the species Helicometra fasciata infecting the intestine of Trachinus draco from the Bay of Bizerte, with a low prevalence of $4.21 \%$. This species was previously reported in Trachinus draco from Turkey (AKMIRZA, 2004).

Aspinatrium trachini was recorded for the first time from trachinid fishes in tunisian waters. According to the literature data, this monegenean species has been reported in $T$. draco from Spain (LOPEZ-ROMAN \& GUEVARAPOZO, 1973), in T. radiatus from Greece (PAPOUTSOGLOU, 1976), and in T. araneus from Montenegro (RADUJKOVIĆ \& EUZET, 1989). Infection caused by $A$. trachini was observed only in the Bay of Bizerte. It seems that the environmental conditions in particular water temperature stimulate the development of $A$. trachini. Indeed, the higher temperatures were recorded in the Bay of Bizerte, which can influence the parasite abundance and the egg production in monogenean life cycle. The present results are supported by other studies where the highest mean intensity and abundance were found in spring and summer (RAWSON \& ROGERS, 1973; KADLEC et al. 2003; OZTURK \& ALTUNEL, 2006; MARTINS et al. 2014).

The Gnathiid isopods are the most common ectoparasites infecting a wide host range of fish worldwide. The present study report the presence of praniza larvae from trachinids in different sampling sites. These larvae belong to the genus Gnathia. According to literature, parniza larvae of Gnathia $s p$. have been previously reported in $T$. draco, $T$. radiatus and T. araneus from North African Mediterranean coasts (RAMDANE et al. 2009).

The Leeches are parasites of various fish species, little is known about the distribution of these parasites in Tunisia. In the present study Stibarobdilla loricata was reported for the first time from Trachinus draco from Tunisian coasts with a very low prevalence (1\%). However, this species was previously reported in Trachinus draco from Turkey by AKMIRZA (2004).

In the present study, the species richness (SR) of trachnids was relatively important. Indeed, each fish host presented at least seven parasites species. The highest SR was recorded in T. Araco. According to Simpson index, $T$. draco carried the highest parasite diversity. This result was confirmed by Shannon index, thus, the maximal value was observed in T. draco. However, the Shannon-Weaver index was the same for T. araneus and T. radiatus.

The important SR and diversity of parasitic species found in $T$. draco, could be explained by the higher number of the examined fish 
(519) compared to the other fish host species. Moreover, T. draco may be more susceptible to the infection by parasites, compared to the other trachinid fishes.

Concerning diversity of the parasite metacommunities according to the sampling sites, the Bay of Bizerte presented the richest community followed by Mahdia. The two other sites, Gulf of Tunis and Sousse showed a less important species richness. The values of the ShannonWiener and Simpson's index show the richest diversity of parasite species in the Bay of Biz- erte. Parasite diversity in relation to the locality can be affected by the seasons; in fact the sampling period was different in the fourth sampling sites. On the other hand, each sampling site was characterized by specific environmental conditions such as temperature and salinity, which may influence the development of the different parasites species. In addition to the presence of appropriate environmental conditions for the parasite, abundance of appropriate intermediate hosts can affect the parasite diversity.

\section{REFERENCES}

ABDEL-BAKI, A.A., H. SOLIMAN., M. SALEH., S. ALQURAISHY \& M. EL-MATBOULI. 2015. Ortholinea saudii sp. nov. (Myxosporea: Ortholineidae) in the kidney of the marine fish Siganus rivulatus (Teleostei) from the Red Sea, Saudi Arabia. Dis. Aquat. Organ., 113: 25-32.

AJALA, O.O. \& O.O. FAWOLE. 2014. Multiple Infections of Helminths in the Stomach and Intestine of Clarias Gariepinus (Burchell, 1822) in Oba Reservoir, Oyo State, Nigeria. J. Pharm. Biol. Sci., 9: 05-12.

AKMIRZA, A. 2004. Parasite Fauna of Greater weever Trachinus draco (Linnaeus, 1758). Acta Adriat., 45: 35-41.

AZIZI, R., L.F. RANGEL., R. CASTRO., M.J. SANTOS \& S. BAHRI. 2016. Morphology, seasonality and phylogeny of Zschokkella trachini n. sp. (Myxozoa, Myxosporea) infecting the gallbladder of Greater Weever Trachinus draco (L.) from Tunisian waters. Parasitol. Res., DOI 10.1007.

BAGHERPOUR, A., M. AFSHARNASAB., I. MOBEDI \& M. MESBAH. 2011. Prevalence and intensity of internal parasitic helminthes infected Black sole fish, Brachirus orientalis (Bloch and Schneider, 1801) in the Persian Gulf. Iran. J. Fish. Sci., 10: 570-584.

BUSH, A.O., K.D. LAFFERTY., J.M. LOTZ \& A.W. SHOSTAK. 1997. Parasitology meets ecology on its own terms: Margolis et al., Revisited. J. Parasitol., 83: 575-583.

CANNING, E.U., A. CURRY., C.L. ANDERSON \& B. OKAMURA. 1999. Ultrastructure of Myxidium trachinorum sp. nov. from the gallbladder of the lesser weever fish Echiichthys vipera. Parasitol. Res., 85: 910-919.

CANNING, E.U. \& B. OKAMURA. 2004. Biodiversity and evolution of the Myxozoa. Adv. Parasitol., 56: 43-131.

DILLON, W.A \& W.J. HARGIS. 1965. Monogenetic trematodes from the southern Pacific Ocean 2. Polyopisthocotyleids from New Zealand fishes: The families Discocotylidae, Micrococotylidae, Axinidae, and Gastrococotylidae. In Biology of the Antractic seas II. Antractic Research series, American Geophysical Union; 5: 251-280

EIRAS, J.C. 2006. Synopsis of the species of Ceratomyxa Thelohan, 1892 (Myxozoa: Myxosporea: Ceratomyxidae). Syst. Parasitol., 65: 49-71.

EIRAS, J.C., Y.S. LU., D.I. GIBSON., I. FIALA., A. SARAIVA., C. CRUZ \& M.J. SANTOS. 2012. Synopsis of the species of Chloromyxum Mingazinni, 1890 (Myxozoa: Myxosporea: Chloromyxidae). Syst. Parasitol., 83: 20325.

FARJALLAH, S., B.B. SLIMANE., M. BUSI., L. PAGGI., N. AMOR., H. BLEL, K. SAID \& S. D'AMELIO. 2008. Occurrence and molecular identification of Anisakis spp. from the North African coasts of Mediterranean Sea. Parasitol. Res., 102: 371-379.

FONTES, I., L.H. SASCHA \& A.M. TOR. 2015. Chapter 17 Comparative Epidemiology of Myxozoan Diseases. In: B. Okamura, A. Gruhl \& 
J. Bartholomew (Editors). Myxozoan Evolution, Ecology and Development. Springer International Publishing, pp. 317-341.

GEORGES, V. 1982. Helminthes parasites des Poissons de mer des côtes du Sénégal. Bulletin de 1'1.F.A.N. T., 44: 1-2.

GUNTER, N. \& R. ADLARD. 2010. The demise of Leptotheca Thelohan, 1895 (Myxozoa: Myxosporea: Ceratomyxidae) and assignment of its species to Ceratomyxa Thelohan, 1892 (Myxosporea: Ceratomyxidae), Ellipsomyxa Koie, 2003 (Myxosporea: Ceratomyxidae), Myxobolus Butschli, 1882 and Sphaerospora Thélohan, 1892 (Myxosporea: Sphaerosporidae). Syst. Parasitol., 75: 81-104.

HORTON, T. 2000. Cerathothoa Steindachneri (Isopoda: Cymotoidae) new to British waters with a key to north-east and Mediterranean Cerathothoa. J. Mar. Biol., 80: 1041-1052.

JUSTINE, J.L., M.J. BRIAND \& R.A. BRAY. 2012. A quick and simple method, usable in the field, for collecting parasites in suitable condition for both morphological and molecular studies. Parasitol. Res., 111: $34-351$.

KADLEC, D., SIMKOVÁ. A. \& M. GELNAR. 2003. The microhabitat distribution of two Dactylogyrus species parasitizing the gills of the barbell, Barbus barbus. J Helminthol., 77: 317-325.

KARLSBAKK, E. \& M. KøIE. 2011. Morphology and SSU rDNA sequences of Ortholinea orientalis (Shulman and Shulman-Albova, 1953) (Myxozoa, Ortholineidae) from Clupea harengus and Sprattus sprattus (Clupeidae) from Denmark. Parasitol Res., 109: 139-45.

KENT, M.L., K.B. ANDREE, J.L. BARTHOLOMEW, M. EL-MATBOULI, S.S. DESSER, R.H. DELVIN, S.W. FEIST, R.P. HEDRICK, R.W. HOFFMANN, J. KHATTRA, S.L. HALLETT, R.J.G. LESTER, M. LONGSHAW, O. PALENZUELA, M.E. SIDDALL \& C.X. XIZO. 2001. Recent advances in our knowledge of the Myxozoa. J. Eukaryot. Microbiol., 48: 395-413.

LOM, J. \& J.R. ARTHUR. 1989. A guideline for the preparation of species descriptions in Myxosporea. J. Fish. Dis., 12: 151-156.

LOM, J. \& I. DYKOVÁ. 2006. Myxozoan gen- era: definition and note on taxonomy, lifecycle terminology and pathogenic species. Folia Parasitol., 53: 1-36.

LOPEZ-ROMAN, R. \& D. GUEVARA POZO. 1973. Species of the family Microcotylidae (Monogenea) from marine teleosts of the Granada Coast. Rev. lber. Parasitol., 3: 97-233.

MANSOUR, L., A.S. ABDEL-BAKI., A.F. TAMIHI \& S. AL-QURAISHY. 2016. Ceratomyxa bohari sp. n. (Myxozoa: Ceratomyxidae) from the gall bladder of Lutjanus bohar Forsskål, 1775 from the Red Sea coast off Saudi Arabia: morphology, seasonality and SSU rDNA sequence. Folia Parasitol., 63: 001.

MARGOLIS, L., G.W. ESCH., J.C. HOLMES., A.M. KURIS \& G.A. SHAD. 1982. The use of ecological terms in parasitology. (Report of an ad hoc committee of the American Society of Parasitology). J. Parasitol., 68: 131-133.

MARTINS, M.L., S.Á. ARS., G.T. JERÔNIMO, K.R. TANCREDO, E.L.T. GONÇALVES, D. BAMPI, G.M. SPECK \& A.M. SANDIN. 2014. Microhabitat preference and seasonality of gill monogenean in Nile Tilapia reared in southern Brazil. Neotrop. Helminthol., 8: 47 - 58.

MCGEORGE, J., C. SOMMERVILLE \& R. WOOTTEN. 1996. The epizootiology of Sphaerospora truttae (Myxozoa: Myxosporea) infections of Atlantic salmon, Salmo salar L. at freshwater smolt producing hatcheries in Scotland. Dis. Aquat. Organ., 26: 33-41.

MORAVEC, F. 2006. Dracunculoid and anguillicoloid nematodes parasitic in vertebrates. Academia, Prague., 634 pp.

ÖKTENER, A. \& J.P. TRILLES. 2004. Report on the Cymothoids (Crustacea, Isopoda) collected from marine fishes in Turkey. Acta Adriat., 45: $15-23$.

OLASUNMIBO OLUMUYIWA, A. \& F.O OLATUNDE. 2015. Studies on aspects of morphometry and enteroparasitic infestation of Sarotherodon galilaeus (Linnaeus, 1758) (Cichlidae) in Oba reservoir, Ogbomoso, Nigeria. Int. J. Fish. Aquat. Stud., 3: 184-191.

ORECCHIA, P. \& L. PAGGI. 1978. Aspetti di sistematica e di ecologia degli elminti parassiti di pesci marini studiati presso l'Istituto di Parassitologia dell'Università di Roma. 
Parasitol., 20: 73-89.

ÖZTÜRK, M.O \& F.N. ALTUNEL. 2006. Occurrence of Dactylogyrus infection linked to seasonal changes and host fish size on four cyprinid fishes in Lake Manyas, Turkey. Acta Zool. Acad. Sci. Hung., 52: 407-415.

PETTER, J.A. \& C. MAILLARD. 1988. Larves d'Ascarides parasites de Poissons en Méditerranée Occidentale. Bull. Mus. nam. Hist, nat., 10: 347-369.

RADUJKOVIĆ, B.M. \& L. EUZET. 1989. Parasites des poissons marins du Monténégro: Monogènes. Acta Adriat., 30: 51-135.

RAMDANE, Z., M.A. BENSOUILAH \& J.P. TRILLES. 2009. Étude comparative des crustacés isopodes et copépodes ectoparasites de poissons marins algériens et marocains. Cybium., 33: 123-131.

RANGEL, L.F., S. ROCHA., M.H. BORKHANUDDIN., G. CECH., R. CASTRO., G. CASAL., C. AZEVEDO, R. SEVERINO., C. SZÉKELY \& M.J. SANTOS. 2014. Ortholinea auratae n. sp. (Myxozoa, Ortholineidae) infecting the urinary bladder of the gilthead seabream Sparus aurata (Teleostei, Sparidae), in a Portuguese fish farm. Parasitol. Res., 113: 3427-37.

RANGEL, L.F., S. ROCHA., G. CASAL., R. CASTRO., R. SEVERINO., C. AZEVEDO., F. CAVALEIRO \& M.J. SANTOS. 2016. Life cycle inference and phylogeny of Ortholinea labracis n. sp. (Myxosporea: Ortholineidae), a parasite of the European seabass Dicentrarchus labrax
(Teleostei: Moronidae), in a Portuguese fish farm. J. Fish. Dis., doi: 10.1111.

RAWSON, M.V \& ROGERS, W.A. 1973. Seasonal abundance of Gyrodactylus macrochiri Hoffman and Putz, 1964 on bluegill and largemouth bass. J. Wildl. Dis., 9: 174-177.

ROCHA, S., G. CASAL., L.F. RANGEL., R. CASTRO., R. SEVERINO., C. AZEVEDO \& M. J. SANTOS. 2015. Ultrastructure and phylogeny of Ceratomyxa auratae n. sp. (Myxosporea: Ceratomyxidae), a parasite infecting the gilthead seabream Sparus aurata (Teleostei: Sparidae). Parasitol. Int., 64: 305-313.

STOSSICH, M. 1896. Ricerche elmintologiche. Boll. Soc. Adriat. Sci. Nat., 17: 121-136.

THABET, A., L. MANSOUR., S.Y. AL OMAR \& Z.S. TLIG. 2015. Ceratomyxa tunisiensis n. sp. (Myxosporea: Bivalvulida) from the Gallbladders of Two Carangid Fish Caught Off the Coast of Tunisia. J. Eukaryot. Microbiol., 63: 86-92.

TRILLES, J.P., B.M. RADUJKOVIĆ \& B. ROMESTAND. 1989. Parasites des poisons marins du Monténégro: Isopodes. Acta Adriat., 30: 279-306.

YOKOYAMA, H., D. GRABNER \& S. SHIRAKASHI. 2012. Transmission biology of the Myxozoa. In: Carvalho ED (Editor) Health and environment in aquaculture. In: Tech, Online, pp 3-42.

YOKOYAMA, H. 2003. A review: gaps in our knowledge on myxozoan parasites of fishes. Fish Pathol., 38: 125-136.

Received: 20 October 2016

Accepted: 13 February 2017 


\title{
Metazoični nametnici kod paukovki (Teleostei: Trachinidae) sa obala Tunisa (Sredozemno more)
}

\author{
Ramla AZIZI, Chiraz YEMMEN* i Sihem BAHRI \\ "Kontakt e-adresa: chiraz_yemmen@yahoo.fr
}

\begin{abstract}
SAŽETAK
U ovom radu se iznose istraživanja nametnika kod predstavnika porodice Trachinidae: Trachinus draco Linnea, 1758; Trachinus araneus Cuvier, 1829. i Trachinus radiatus Cuvier, 1829, koji su prikupljeni sa obala Tunisa. Istraživanje je trajalo od siječnja 2014. do siječnja 2015. godine. Ukupno je utvrđeno 18 vrsta metazoičnih nametnika iz 13 rodova: devet iz Myxozoa, četiri iz Nematoda, jedna iz Cestoda, jedna iz Digenea, jedna iz Monogenea, jedna iz Isopoda i jedna iz Annelida Hirudinea. Tijekom znanstvenog istraživanja istraživani su podaci o morfologiji, lokaciji i razini infekcije parazita.

Veće bogatstvo vrsta zabilježeno je kod Trachinus draco (18 vrsta), dok su Trachinus radiatus i Trachinus araneus imali 9 i 7 vrsta. Navodi se bogatstvo i raznolikost vrsta prema vrstama domaćina i lokacijama uzorkovanja na temelju Simpson i Shannon-Wiener indeksa.
\end{abstract}

Ključne riječi: Trachinidae, metazoični nametnici, raznolikost vrsta, Tunis 
